\title{
The Impacts of Artificial Intelligence on Research in the Legal Profession
}

\author{
Samuel Maireg Biresaw ${ }^{*}$ \\ ${ }^{1}$ LLB, LLM in Business Law, LLM in International Commercial and Business Law (University of East Anglia, \\ UK), Lecturer in Laws, Debre Tabor University School of Law \\ *Correspondence: samregfen@gmail.com or https://orcid.org/0000-0001-7078-3643
}

\begin{abstract}
Legal research is an indispensable skill for lawyers. Therefore, it is always necessary for lawyers to engage in legal research in due course of trying to alleviate various legal problems. Although the purpose and methodology of the research may vary from lawyer to lawyer, doing research is a common activity. As a result, the quest to assess the impacts of artificial intelligence (hereinafter 'AI') on legal research allows one to measure the influence of AI on the legal profession in general. Moreover, with the advent of Legal AI, it is now evident that the legal profession is not immune from disruption. According to the above, this article discusses the impacts of $\mathrm{AI}$ on research in the legal profession in general in accomplishing various lawyerly tasks by different legal professionals.
\end{abstract}

\section{Key Words}

Artificial intelligence; Legal research; Disruption; Legal AI tools

\section{Introduction}

Legal research, which refers to the process of identifying, analyzing, and applying the law to solve a particular problem, is a core lawyering skill that significantly contributes to almost every aspect of legal practice. ${ }^{1}$ There is no particular field in the legal profession that does not involve the underway of legal research. ${ }^{2}$ Hence, legal research is determinant to almost all the activities of legal professionals. ${ }^{3}$ Although different professionals may undertake different types of research in scope, nature, and magnitude, researching the law is a common

\footnotetext{
${ }^{1}$ Mike McConville \& Wing Hong Chui, Research Methods for Law (Edinburgh University Press 2007) 7, 8.

${ }^{2}$ Carol M. Bast \& Margie Hawkins, Foundations of Legal Research and Writing (4th edn., Delmar Cengage Learning 2010) 9; Amy E. Sloan, Basic Legal Research, Tools and Strategies ( $7^{\text {th }}$ edn., Wolters Kluwer 2018) 12.

${ }^{3}$ P M Bakshi, Legal Research and Law Reform, in S K Verma \& M Afzal Wani, Legal Research and Methodology $\left(2^{\text {nd }}\right.$ edn, Indian Law Institute 2001) 111-137.
} 
denominator to accomplish the tiniest of legal tasks. ${ }^{4}$ Therefore, it is not an exaggeration to conclude that the quality of legal services rendered by lawyers is directly dependent on the quality of the research undertaken to that effect. ${ }^{5}$

Due to the above correlation, when one tries to measure the impact of AI on legal research, implicitly s/he is also assessing the impact of AI on the entirety of legal practice. This is because (1) almost all activities in law are done through the instrumentality of legal research, and therefore (2) all types of legal professionals necessarily engage in legal research to accomplish legal tasks. ${ }^{6}$ For example, legal research can be done by judges ${ }^{7}$, practicing lawyers $^{8}$, legislators ${ }^{9}$, Arbitrators, law professors and students $^{10}$, paralegals ${ }^{11}$, legal aid providers, law clerks, law librarians, private investigators, law enforcement officials, writers, authors, and other institutions. ${ }^{12}$

Accordingly, this article contains five parts. Part one deals with the historical background of AI. Then part two discusses the definition of AI. Then, part three discusses the definitions and conceptual analysis of Legal research. Thereafter, part four discusses the positive impacts of $\mathrm{AI}$ on research in the legal profession and legal AI tools currently impacting legal research. Then part five discusses the negative impacts of AI on research in the legal profession. Then, the last part deals with the conclusion of the study.

\section{The Historical Background of Artificial Intelligence}

In 1950, British mathematician Alan Turing published a paper on computing machinery and intelligence posing the question of whether machines can think. ${ }^{13}$ However, the term AI was put to use for the first time in August 1955 in the Dartmouth Summer Research Conference Project Proposal authored by John McCarthy, Marvin L. Minsky, Nathaniel Rochester, and

\footnotetext{
${ }^{4}$ J. C. Thomas, 'A Modest Programme for the Improvement of Law Teaching', (1978) 9 (4) Victoria University of Wellington Law $\quad$ Review 405,4 <https://heinonline.org/HOL/handle=hein.journals/vuwlr9\&div=6\&id=\&page=> accessed 06 July 2021.

5 T. Hutchinson, Researching and Writing in Law (2 ${ }^{\text {nd }}$ edn., Pyrmont NSW 2006) 7.

${ }^{6}$ Dawn Watkins \& Mandy Burton, Research Methods in Law (2 ${ }^{\text {nd }}$ edn., Routledge Publisher 2018) 8, 9.

${ }^{7}$ Frederick C Hicks, Materials and Methods of Legal Research ( $3^{\text {rd }}$ edn., Lawyers Cooperative Pub. Co 1942) $23,31$.

${ }^{8}$ D. W. Vick, 'Interdisciplinary and the Discipline of Law', (2004) 31 (2) Journal of Law and Society 163,177 $<$ https://doi.org/10.1111/j.1467-6478.2004.00286.x > accessed 06 July 2021

9 John C Wahlke \& Heinz Eulau, Legislative Behavior-A Reader in Theory and Research (Free Press of Glencoe 1959) 413.

${ }^{10}$ Amy E. Sloan, Basic Legal Research, Tools and Strategies (7th edn., Wolters Kluwer 2018) 12.

${ }^{11}$ Edward A. Nolfi, Basic Legal Research for Paralegals (2 $2^{\text {nd }}$ edn., Iriwin Publishers 2008) 15.

12 Valerie Atkinson Brown, Legal Research via the Internet (West Thomson Publishers 2001) 23.

${ }^{13}$ OECD (2019), Artificial Intelligence in Society, OECD Publishing, Paris, p 20, <https://doi.org/10.1787/eedfee77-en> accessed 06 July 2021
} 
Claude Shannon. ${ }^{14}$ John McCarthy, who is typically thought to have coined the term AI was an American computer and cognitive scientist, and one of the founders of the AI discipline. Marvin Lee Minsky was an American cognitive scientist in the field of AI and one of the main AI theorists. ${ }^{15}$

When it comes to the use and application of AI in the legal profession, AI has been in use within the meaning attributed to it by computer science since the $1960 \mathrm{~s} .{ }^{16}$ Computer-Assisted Legal Research (CALR) debuted in the mid-1960s, but the first CALR systems were primitive by today's standards and not widely available. ${ }^{17}$

The CALR revolution gained ground with the introduction of Lexis in 1973, which was the first commercial, full-text, electronic database of case law and was aggressively marketed to attorneys and judges. ${ }^{18}$ In the same year, four New York law firms subscribed to the Lexis legal information service. ${ }^{19}$ This event ushered in the start of a new era for legal technology. The Lexis service rapidly expanded because for the first time lawyers had a comprehensive and searchable electronic access to case law, unprecedented in size and scope, which greatly simplified the research process. ${ }^{20}$

West Publishing Company followed Lexis in entering the electronic legal research market in 1975. The initial Lexis and Westlaw databases were much more limited. By the mid-1980s, both systems offered a considerable selection of international legal authorities. By 1990, LexisNexis was processing 100,000 online searches in one day; by 1998, that number grew to 600,000. By 1994, nearly all major law firms in the United States had access to Lexis and

\footnotetext{
${ }^{14}$ Alzbeta Krausova, 'Intersections between Law and Artificial Intelligence, International Journal of Computer' (IJC) (2017) 27 (1), 55, 68. <https://core.ac.uk/download/pdf/229656008.pdf> accessed 06 July 2021

${ }^{15}$ Daniel Ben-Ari, Yael Frish, Adam Lazovski, Uriel Eldan, \& et al, 'Artificial Intelligence in the Practice of Law: An Analysis and Proof of Concept Experiment' (2017) 23 (2) Rich. J. L. \& Tech. 3, 53 $<$ http://jolt.richmond.edu/index.php/volume23 issue2_greenbaum/> accessed 06 July 2021

${ }^{16}$ Richard E. Susskind, Artificial Intelligence, Expert Systems and Law, (1990) 5 (1) the Denning Law Journal 105, 116 <http://bjll.org/index.php/dlj/article/view/196> accessed 06 July 2021

${ }^{17}$ Catalina Goanta, Gijs van Dijck, Gerasimos Spanakis, Back to the Future: Waves of Legal Scholarship on Artificial Intelligence, Forthcoming in Sofia Ranchordás and Yaniv Roznai, Time, Law and Change (Oxford, Hart Publishing, 2019)

${ }^{18}$ Paul Hellyer, Assessing the Influence of Computer-Assisted Legal Research: A Study of California Supreme Court Opinions (2005) <https://scholarship.law.wm.edu/libpubs/5> accessed 06 July 2021

${ }^{19}$ Katherine Medianik, 'Artificially Intelligent Lawyers Updating the Model Rules of Professional Conduct in accordance with the Technological Era' (2018) 39 Cardozo Law Review 1498, 1530 $\langle$ http://cardozolawreview.com/wp-content/uploads/2018/07/MEDIANIK.39.4.pdf> accessed 06 July 2021

20 Stephen Miller, 'For Future Reference, a Pioneer in Online Reading' (2012) WALL ST. J. <http://www.wsj.com/articles/SB10001424052970203721704577157211501855648> accessed 06 July 2021
} 
Westlaw. ${ }^{21}$ Currently, LexisNexis had 15,000 databases and over 9 million subscribers worldwide and Westlaw is one of the primary online legal research services for lawyers and legal professionals in the United States, the United Kingdom, and Australia with more than 40,000 databases of legal information. ${ }^{22}$

Then, machine intelligence, which is already extraordinarily advanced in discovery, was put to use. Electronic discovery, also known as 'e-discovery', is the "process by which computers search a database for keywords that lawyers agree are marks of relevance." Courts and the U.S. Department of Justice have already approved predictive coding as a tool for discovery. Specifically, the United States District Court, S.D. New York in Moore v. Publicis Groupe held that computer-assisted review could now be considered "judicially-approved for use" in appropriate cases. ${ }^{23}$

Scholars also predict that AI will soon be able to draft legal briefs and memoranda by collaborating up with legal research programs and will be able to conduct predictive analytics to predict case outcomes by relying on data patterns. ${ }^{24}$ Besides, machine intelligence is continuing to revolutionize the use of legal forms by tailoring various forms to meet individual situations. ${ }^{25}$

At present, AI is becoming a hot topic in the legal world. ${ }^{26}$ As stated by Mr. Andrew Arruda, the Director of Ross Intelligence, ROSS, the world's first AI lawyer, built on IBM's cognitive computer 'Watson', was designed to read and understand natural language, postulate hypotheses when asked questions, conduct legal research, and write thorough legal memoranda, along with references and citations. Essentially, ROSS uses algorithms to mimic the human brain's learning, analytical, and decision-making processes. ${ }^{27}$

\footnotetext{
${ }^{21}$ Hellyer, Paul, 'Assessing the Influence of Computer-Assisted Legal Research: A Study of California Supreme Court Opinions' (2005) Library Staff Publications 5 <https://scholarship.law.wm.edu/libpubs/5> accessed 06 July 2021

22 John O. McGinnis and Russell G. Pearce 'The Great Disruption: How Machine Intelligence Will Transform the Role of Lawyers in the Delivery of Legal Services', (2014) 82 Fordham Law Review 3041 <https://ir.lawnet.fordham.edu/flr/vol82/iss6/16> accessed 06 July 2021

${ }^{23}$ Moore vs Publics Groupe, 287 F.R.D. 182182 (S.D.N.Y. 2012)

${ }^{24}$ Ibid, John O. McGinnis and Russell G. Pearce supra note 22

${ }^{25}$ Mary Ann Neary \& Sherry Xin Chen, 'Artificial Intelligence: Legal Research and Law Librarians' (2017) AALL SPECTRUM 16, 20 <https://lawdigitalcommons.bc.edu/lsfp/1073/> accessed 06 July 2021

26 Hannah Augur, 'AI Is the Future of Law - And Lawyers Know It', (2016) Dataconomy <http://www.dataconomy.com/ai-future-law-lawyers-know> accessed 06 July 2021

27 Andrew Arruda, 'Artificial Intelligence Systems and the Law' (2016) Peer To Peer Mag. 38,39 <http://epubs.iltanet.org/i/696855-summer-2016/37> accessed 06 July 2021
} 
Accordingly, the legal field is currently intrigued by the addition of AI technology in the workplace, and rightfully so. Older lawyers have never imagined such technological advancement and young lawyers are undoubtedly attracted to it. With this mindset, not only will the use of cutting-edge AI technology lure lawyers to firms, it will lure clients in as well. $^{28}$

Regarding AI research, from 1960 until early 2018, nearly 340,000 patent families and more than 1.6 million scientific papers related to AI were published. The number of patent applications filed annually in the AI field grew by a factor of 6.5 between 2011 and 2017. AI is also a major topic in scientific literature, with $1,636,649$ papers published up to mid$2018 .^{29}$

Therefore, it is not an exaggeration to conclude that, in the last 25 years, due to the advent of technology every aspect of legal practice (such as legal education, hiring, client acquisition, communication, and maintenance, court docketing, and judicial workflow; and discovery production) has changed. ${ }^{30}$

On the other hand, from 2012-2018 increased availability of data, connectedness, and computational power allowed for breakthroughs in machine learning, mainly in neural networks and deep learning, heralding a new era of increased funding and optimism for innovation in the entire field of AI in general and in legal tech startups in particular. ${ }^{31}$ For example in the UK, the UK Digital Strategy published in March 2017 allocated millions of pounds in funding for UK universities to develop AI technologies. ${ }^{32}$

Finally, the release of Apple's 'Siri' in 2011, the defeat of the two human champions by IBM's 'Watson' at the TV quiz named 'Jeopardy' in 2011, the autonomous navigation of Google's driverless cars in 2012, and the defeat of the world champion (Mr. Lee Sedol) by

\footnotetext{
${ }^{28}$ Sterling Miller, 'Ten Things: Artificial Intelligence-What Every Legal Department Really Needs to Know' (2017) 1 <https://sterlingmiller2014.wordpress.com/2017/08/15/> accessed 06 July 2021

${ }^{29}$ WIPO 'Technology Trends 2019 Artificial Intelligence', 39

${ }^{30}$ Alyson Carrel, 'Legal Intelligence Through Artificial Intelligence Requires Emotional Intelligence: A New Competency Model for the 21st Century Legal Professional' (2019) 35 (4) Georgia State U. L. Rev. 1153, 1183 <https://readingroom.law.gsu.edu/gsulr/vol35/iss4/4> accessed 06 July 2021

${ }^{31}$ Daniel Ben-Ari \& et al, supra note 15, 3, 53

${ }^{32}$ The OECD, 'Artificial Intelligence in Society' (2019) OECD Publishing 36,47 <https://doi.org/10.1787/eedfee77-en> accessed 06 July 2021
} 
Google's 'AlphaGo' in the complicated board game of 'Go' in 2016 were typical milestones in the recent development of AI. ${ }^{33}$

\section{Definition of Artificial Intelligence}

An AI system, as explained by the OECD's AI Experts Group (AIGO), is a system based on algorithms and self-learning guided by machine learning and deep learning, which can perform certain human cognitive capabilities by interacting with the environment through sensors, processing information, and adopting decisions and taking actions, with a certain degree of autonomy. ${ }^{34}$

To discern the true meaning of AI stated above, it is necessary to define its constituent elements, which are, an algorithm, machine learning, and deep learning.

Accordingly, an 'algorithm' is a finite sequence of automated procedures (instructions, rules, or actions) executed systematically at a much higher speed to solve a given class of problems. ${ }^{35}$ Hence, an algorithm-driven system constitutes a structured process to provide a solution to any instance of a recurrent problem. It is via the implementation of algorithmdriven systems that it is possible to automate a variety of decisions, tasks, or processes such as data classifying, searching, scoring, ordering, ranking, selecting, and filtering. ${ }^{36}$ The very purpose of an algorithm is programming through instructions with the view that such instruction-based programming will entail predictability, as the outcomes are essentially the expected results of the pre-conditions, the decision criteria, and the algorithm design. ${ }^{37}$

The other main component of AI is 'Machine learning'. It refers to the parsing of data to learn, predict, and adopt a decision based on a set of variables. ${ }^{38}$ Machine learning is so revolutionary because programs using this process learn how to give the proper outputs, i.e., correctly accomplish their tasks (or become better), with limited or no instruction as to how

\footnotetext{
${ }^{33}$ WIPO Technology Trends, 'Artificial Intelligence' (2019) 19; OECD (2019), 20; See 'Go the Movie" on YouTube, <https://www.youtube.com/watch?v=WXuK6gekU1Y>; Steven Livingston and Mathias Risse, 'The Future Impact of Artificial Intelligence on Humans and Human Rights' (2019) 33 (2) Ethics \& International Affairs 141, 158 <https://www.hks.harvard.edu/publications/future-impact-artificial-intelligence> accd. 06/2021 ${ }^{34}$ The OECD 2019, supra note 32

${ }^{35}$ Whittlestone J., Nyrup R., Alexandrova A., \& et al., 'Ethical and societal implications of algorithms, data, and artificial intelligence: a roadmap for research' (2019) London: Nuffield Foundation 1, 59 <https://www.nuffieldfoundation.org/sites/default/files/files/Ethicalpdf> accessed 06 July 2021

36 Teresa Rodriguez de las Heras Ballell, 'Legal Challenges of Artificial Intelligence: Modeling the Disruptive Features of Emerging Technologies and Assessing their possible Legal Impact' (2019) 24 University of Florida L. Rev. 302, 314 <https://academic-oup-com.eres.qnl.qa/ulr/article-abstract/24/2/302/5526861> accesd. 06/2021

37 Steven Livingston and Mathias Risse, supra note 33

38 Zoubin Ghahramani, 'Probabilistic Machine Learning and Artificial Intelligence' (2015) 521 Nature 452,459 <https://www.nature.com/articles/nature14541> accessed 06 July 2021
} 
they should accomplish the specific task. These programs use 'iteration', a process of repetitively feeding data into an algorithm to improve their outputs. Over time, these programs can make their judgments based on previous data from similar but not identical tasks. ${ }^{39}$

On the other hand, 'deep learning' is a technique within machine learning tools that aims to enable example-based learning of machines and autonomous systems. ${ }^{40}$ Instead of instructing the system with a set of pre-determined instructions, deep learning provides a model for the machine to evaluate examples and infer patterns for the solving of future problems. It is from the harmonious application of the stated components that AI will be capable of processing a given instruction and provide a required outcome. ${ }^{41}$

Accordingly, AI is viewed as an artificial system that performs tasks under varying, but predictable circumstances and without significant human oversight. Such systems could also learn from their experiences while improving their performances (for the future) and might even solve tasks requiring human-like perception, cognition, planning, learning, communication, or physical actions. ${ }^{42}$

On the other hand, given its elusive nature, different professionals have defined AI differently from different perspectives. This made it difficult to coin a universally agreeable definition of AI. For example, from the perspective of what it is made up of, AI can be portrayed as a system that includes both hardware and software components, which may refer to a robot, a program running on a single computer, a program run on networked computers, or any other set of components that hosts an $\mathrm{AI}^{43}$

From the viewpoint of legal recognition, AI is most often considered as work resulting from intellectual activity that can be protected by intellectual property law as software ${ }^{44}$ through

\footnotetext{
${ }^{39}$ Sean Semmler \& Zeeve Rose, 'Artificial Intelligence: Application Today and Implications Tomorrow' (2017) 16 Duke Law \& Technology Review 85, 99 <https://scholarship.law.duke.edu/dltr/vol16/iss1/3> acesd. 06/2021

40 Jeff Hawkins, 'What Intelligent Machines Need to Learn from the Neocortex' (2017) IEEE Spectrum 1 <https://spectrum.ieee.org/computing/software/what-intelligent-machines> accessed 06 July 2021

${ }^{41}$ Peter Yeoh, 'Artificial Intelligence: Accelerator or Panacea for Financial Crime?' (2019) 26 (2) Journal of Financial Crime 634, 646 <https://heinonline.org/hol-cgi-bin/get_pdf.cgi?handle> accessed 06 July 2021

${ }^{42}$ Hoadley and Lucas, 'Artificial Intelligence and National Security' (2019) Congressional Research Service 1 $<$ https://fas.org/sgp/crs/natsec/R45178.pdf > accessed 06 July 2021

43 Alzbeta Krausova, supra note 14, 55-68

${ }^{44}$ Lincoln Tsang, Daniel A. K., Jacqueline Mulryne \& et al, 'The Impact of Artificial Intelligence on Medical Innovation in the European Union and United States' (2017) 29 (8) The Intellectual Property \& Technology Law Journal 1, 8 <https://www.arnoldporter.com/en/perspectives/publications/2017/08/> accessed 06 July 2021
} 
copyright. ${ }^{45}$ Under certain conditions, AI can also be protected by a software patent. ${ }^{46}$ The law also accords protection to AI systems that are inseparably incorporated into physical devices such as robots by considering them as products. ${ }^{47}$

From the perspective of its end purpose, AI can be defined as the process of simulating human intelligence through machine processes. ${ }^{48}$ In this regard, the end goal is to create artificially intelligent machines, often in the form of robots that can perform traditionally human tasks better and more efficiently than humans ever could. ${ }^{49}$

Accordingly, experts in the field of AI classify such artificially intelligent machines into two major types: the first is General AI that refers to an extremely complex machine (algorithm or set of algorithms) that think like people across multifaceted problem domains and have the ability to reason generally, which is the goal for the future (currently hypothetical). ${ }^{50}$

The second is called Narrow (applied/ specialized) AI that refers to systems designed to execute specific tasks or a single function, and will never rival the cognitive depth of a human being. ${ }^{51}$ Good examples are playing 'chess' or 'Go', or diagnosing an illness. Narrow AI is already functional in various aspects of human life often with greater accuracy and efficiency than human beings. ${ }^{52}$ It should be noted that these two approaches to AI rely on machine learning, which is the process of teaching a program to learn from user-fed data to

\footnotetext{
${ }^{45}$ M. D. Goldberg, D. O. Carson, 'Copyright Protection for Artificial Intelligence Systems' (1991) 39 (1) Journal of the Copyright Society of the U.S.A. 57, 75 $<$ http://heinonline.org/HOL/Page?handle=hein.journals/jocoso39> accessed 06 July 2021

${ }^{46}$ E. J. Schaal, 'Infringing a Fantasy: Future Obstacles Arise for the United States Patent Office and Software Manufacturers Utilizing Artificial Intelligence' (2004) 11 (1) Villanova Sports \& Entertainment Law Journal 173, $202<$ https://digitalcommons.law.villanova.edu/cgi/viewcontent.cgi?article〉 accessed 06 July 2021

${ }^{47}$ K. Alhelt, 'The Applicability of the EU Product Liability Directive to Software' (2001) 34(2) Comparative and International Law Journal of Southern Africa 188, 209 Available: $\langle$ http://heinonline.org/HOL/Page?handle=hein.journals/ciminsfri34 > accessed 06 July 2021

${ }^{48}$ Sean Semmler \& Zeeve Rose, supra note 39

49 Kris Hammond, 'What is Artificial Intelligence?' (2015) Computer World 1 <https://www.computerworld.com/article/2906336/> accessed 06 July 2021

${ }^{50}$ Steven Livingston and Mathias Risse, supra note 33, General AI is often referred to as "super intelligence" Google's 'Deep-Mind' and 'Google Brain', along with other initiatives at other major tech companies, are pushing AI towards 'super-intelligence'.

51 OECD, 'OECD Digital Economy Outlook' (2017) OECD Publishing, Paris 1 $<$ http://dx.doi.org/10.1787/9789264276284-en> accessed 06 July 2021

52 'Artificial Intelligence and the Legal Profession' (2018) The Law Society of England and Wales, Horizon Scanning Report $1<$ https://www.lawsociety.org.uk/support-services/research-trends/horizon-scanning/artificialintelligence/, Examples of Narrow AI systems are Google's Self Driving Cars, IBM's 'Watson', Apple's 'Siri', 'Google Assistant' or Amazon's 'Alexa', AI-powered 'chatbot doctor', 'Melody', developed by Chinese search giant Baidu, \& Google's AlphaGo etc.
} 
respond to completely new data in the future, without the need to program a specific set of instructions for every possible data point. ${ }^{53}$

From the perspective of its artificial nature, AI can be defined as a non-biological autonomous entity. However, the term autonomous in this definition should be taken as the ability of AI to process data by itself and by no means prohibits any situation in which human and AI experts are working alongside one another (also called co-robotics). ${ }^{54}$

On the other hand, the notion AI is made up of two words "Artificial" which implies a good made by people, often as a copy of something natural, and "Intelligence" which may refer to: "the ability to learn and understand or to deal with new or trying situations", or "the skilled use of reason", or "the ability to apply knowledge to manipulate one's environment or to think abstractly as measured by objective criteria". 55

Accordingly, AI is an artificially developed intelligence, created as an alternative to humans, or a crafted machine with embedded learning and analysis capabilities, mastered to comply with real-life situations and to perform, as much as accurately possible, the tasks and works once done by men. ${ }^{56}$

Simply put, AI is that activity devoted to making machines intelligent, and intelligence is that quality that enables an entity to function appropriately and with foresight in its environment. As famously stated by, the British mathematician Alan Turing, one of the pioneers in the field of AI "a computer would deserve to be called intelligent if it could deceive a human into believing that it was human". 57

However, it should be noted that AI is not intelligent in the sense that it does not know what it is doing, or why it is doing it. An AI system is not really 'reasoning' or 'thinking' but is

\footnotetext{
${ }^{53}$ Sean Semmler and Zeeve Rose, supra note 39

${ }^{54}$ Thomas Julius Buocz 'Artificial Intelligence in Court Legitimacy Problems of AI Assistance in the Judiciary' (2018) 2 (1) 1, Retskraft-Copenhagen Journal of Legal Studies 41, 59 <https://static1.squarespace.com/static/59db92336f4ca35190c650a5/.pdf> accessed 06 July 2021

${ }^{55}$ Maxi Scherer, 'Artificial Intelligence and Legal Decision-Making: The Wide Open Study on the Example of International Arbitration' (2019) Queen Mary University of London, School of Law Legal Studies Research Paper No. 318 1, 33 <https://ssrn.com/abstract=3392669> accessed 06 July 2021

56 Maxim Dobrinoiu, 'The Influence of Artificial Intelligence on Criminal Liability, Challenges of the Knowledge Society' (2019) 140 Criminal Law, Lex ET Scientia Int'l J. 48,52 <http://cks.univnt.ro/download/cks_2019 articles\%252F1_criminal_law\%252FCKS.pdf> accesd. 06 July 2021

57 '16 Artificial Intelligence projects from Deloitte: Practical cases of applied AI Unleash the power of AI for $\begin{array}{lllll}\text { your organization' (2018) Netherlands } & \text { Deloitte } & \text { 5, }\end{array}$ <https://www2.deloitte.com/content/dam/Deloitte/n1/Documents/.pdf > accessed 06 July 2021
} 
following a set of pre-programmed computational steps (expert systems) or mathematically analyzing a huge amount of data to infer a probability (machine learning). ${ }^{58}$

As adequately emphasized by Steven Pinker, AI does not have intentionality or a real attitude, but only sets tasks and goals; unlike humans, it does not make real judgments based on principles, rules, priorities, or values. ${ }^{59}$

In 1956, Professor John McCarthy, at a conference held in Dartmouth College, New Hampshire, USA was credited with introducing the term 'AI' as: 'the science and engineering of making intelligent machines, especially intelligent computer programs. ${ }^{60}$ Since then AI is portrayed as a machine that behaves in ways that would be called intelligent if a human were so behaving. ${ }^{61}$

Similarly, in 1968 Marvin Minsky, one of the founders of AI, described AI as the science of making machines do things that would require intelligence if done by man. In this sense, AI is pursued at least for two reasons: to understand the workings of human intelligence and to create useful computer programs and computers that can perform intelligently. ${ }^{62}$ Therefore, AI can be broadly characterized as intelligence by machines and software. ${ }^{63}$

Similarly, AI can be practically defined as the theory and development of computer systems that can perform tasks normally requiring human intelligence, such as visual perception, speech recognition, decision-making, and translation between languages. ${ }^{64}$ Thus, it is quite evident from the above definitions that human intelligence is taken as a benchmark to measure AI.

Similarly, Richard Susskind, a prominent expert in AI, defined AI as a field of study concerned with the design, development, and implementation of computer systems that can perform tasks and solve problems of a sort for which human intelligence is normally thought

\footnotetext{
${ }^{58}$ Michael Legg and Felicity Bell, 'Artificial Intelligence and the Legal Profession: A Primer' The Law Society of University of New South Wales: The Future of Law and Innovation in the Profession' (2017) 2, 24 <https://www.allenshub.unsw.edu.au/sites/20Primer.pdf > accessed 06 July 2021

${ }^{59}$ Steven Pinker, Enlightment Now, the Case for Reason, Science, Humanism, and Progress (Penguines Book Limited Publishers, 2018) 35

60 Nachshon Sean Goltz \& Giulia Dondoli (2019) 'A Note on Science, Legal Research and Artificial Intelligence, Information \& Communications Technology Law’ (2019) $28 \quad$ (3) $239, \quad 251$ $<$ https://doi.org/10.1080/13600834.2019.1644065> accessed 06 July 2021

${ }^{61}$ Maxi Scherer, supra note 55, 1, 33

${ }^{62}$ Edwina L. Rissland, 'Artificial Intelligence and Law: Stepping Stones to a Model of Legal Reasoning' 99 (8) Yale Law Journal 1957, 1981 <https://digitalcommons.law.yale.edu/ylj/vol99/iss8/4/> accessed 06 July 2021

${ }^{63}$ Ibid, Daniel Ben-Ari \& et al, supra note 15, 35-36

64 David Schatsky, Craig Muraskin, and Ragu Gurumurthy, 'Demystifying Artificial Intelligence: What Business Leaders Need to Know about Cognitive Technologies’ (Report, Deloitte University Press, 2014) 3
} 
to be required. ${ }^{65}$ So $\mathrm{AI}$ as a field of science and technology is employed where processes are used to carry out tasks, i.e. the processes that mimic, imitate, or simulate intelligence. ${ }^{66}$

AI may also be defined by reference to the tasks it performs (such as visual perception, speech recognition, decision-making, and translation between languages) and the processes used to perform tasks: expert systems, machine learning (supervised, unsupervised, neural networks) and so on. ${ }^{67}$

In general, $\mathrm{AI}$ is an umbrella term that refers to teaching a machine how to do a task that was thought to be human. ${ }^{68}$ That is why, in its January 2018 book, 'The Future Computed' Microsoft defined AI as "a set of technologies that enable computers to perceive, learn, reason and assist in decision-making to solve problems in ways that are similar to what people do." 69

When it comes to AI in the legal profession, it can be conventionally defined as programing computer technologies (such as machine learning, natural language processing, speech recognition, legal robotics, planning, natural image understanding, rule-based expert system, neural networks, logic programming, artificial vision, machine learning, and neural networks) to process, analyze and finalize various legal tasks historically performed by lawyers. ${ }^{70}$

In summary, AI collectively covers a range of technologies from simple software to sentient robots, and everything in between and unavoidably includes both algorithms and data. ${ }^{71}$

\footnotetext{
${ }^{65}$ Richard E. Susskind, 'Artificial Intelligence, Expert Systems and Law' (1990) 5 (1) The Denning Law Journal 105, 116 <http://bjll.org/index.php/dlj/article/view/196> accessed 06 July 2021

${ }^{66}$ Tania Sourdin, 'Judge V Robot? Artificial Intelligence and Judicial Decision Making' (2018) 41 (4) UNSW Law Journal 1114, 1133 <http://www.unswlawjournal.unsw.edu.au/article/> accessed 06 July 2021

${ }^{67}$ Michael Legg and Felicity Bell, supra note 58, 2, 24

${ }^{68}$ Andrew Arruda, 'An Ethical Obligation to Use Artificial Intelligence: An Examination of the Use of Artificial Intelligence in Law and the Model Rules of Professional Responsibility’ (2017) 40 (3) American Journal of Trial Advocacy 443, 459 <https://heinonline.org/hol-cgi-bin/get_pdf> accessed 06 July 2021

${ }^{69}$ Microsoft, The Future Computed Artificial Intelligence and its role in society (Microsoft Corporation 2018) 1, 139 <https://blogs.microsoft.com/blog/2018/01/17> accessed 06 July 2021

70 Jyoti Dabass \& B. S. Dabass, 'Scope of Artificial Intelligence in Law' (2018) 1, 9 <https://pdfs.semanticscholar.org/5162/30d30d972.pdf> accessed 06 July 2021

${ }^{71}$ Kevin D. Ashley, Artificial Intelligence and Legal Analytics: New Tools for Law Practice in the Digital Age (Cambridge University Press 2017) 1, 426
} 


\section{Definition and Conceptual Analysis of Legal Research}

\subsection{Definition of Legal Research}

Legal research can be defined differently from different perspectives. The term is composed of two words, 'Legal' and 'Research'. Accordingly, the term 'research' refers to any gathering of data, information, and facts for the advancement of knowledge. ${ }^{72}$ Similarly, research can be defined as a studious inquiry or examination; especially investigation or experimentation aimed at the discovery and interpretation of facts, revision of accepted theories or laws in the light of new facts, or practical application of such new or revised theories or laws. ${ }^{73}$ Therefore, research is the act of searching into a matter closely and carefully, inquiry directed to the discovery of truth and in particular, the trained scientific investigation of the principles and facts of any subject, based on an original and first-hand study of authorities or experiment. ${ }^{74}$

On the other hand, research can also be portrayed as a process of steps used to collect and analyze information to increase an understanding of a topic or an issue. ${ }^{75}$ Research refers to the process of identification of a problem, the ascertainment of the relevant facts, their logical ordering and classification, the use of logic (science) to interpret the collected and classified facts, and the assertion of conclusions premised on and supported by the collected information. ${ }^{76}$ In this sense, research is a creative and systematic work undertaken to increase the stock of knowledge and to devise new applications of available (existing) knowledge. ${ }^{77}$

It is logical to conclude from the above definitions that 'research' is the careful, diligent, exhaustive, and systematic (scientific) investigation (search/pursuit) of a specific subject matter (knowledge) to know (discovering) the truth and making an original contribution in the existing stock (body) of knowledge.

\footnotetext{
${ }^{72}$ Nachshon S. Goltz \& Giulia Dondoli, supra note 60

73 The Encyclopedia Britannica $16^{\text {th }}$ Edition (2016)

${ }^{74}$ Ibid

${ }^{75}$ Michael Salter and Julie Mason, Writing Law Dissertations, an Introduction and Guide to the Conduct of Legal Research (Pearson Longman Publishers 2007) 1, 245

76 John W. Creswell, Educational Research: Planning, Conducting, and Evaluating Quantitative and Qualitative Research ( $4^{\text {th }}$ ed, Pearson 2012) 1,56

77 Frascati Manual 2015: Guidelines for Collecting and Reporting Data on Research and Experimental Development, The Measurement of Scientific, Technological and Innovation Activities, (OECD Publishing 2015) 43, 195 < https://doi.org/10.1787/9789264239012-en.> accessed 06 July 2021
} 
On the other hand, legal research can be defined as a systematic finding or ascertaining of the law on the identified problem or in the given area as well as an inquiry into law to solve a particular problem or making advancement in the science of law. ${ }^{78}$

Accordingly, in a rough sense, legal research can be described as the process by which lawyers identify (find), read (retrieve), interpret (analyze and synthesize) the content of the law, and explain the law to their clients or to judges or to support legal decision making. ${ }^{79}$ Therefore, legal research is an important part of being a lawyer, and that is why it is believed that the clients are indeed paying a price for the quality of legal research undertaken by lawyers on a particular problem. ${ }^{80}$

However, it should be emphasized that as far as they can access the law and have the required knowledge, non-lawyers can also do legal research, whether to resolve a private dispute, understand and work with a legal professional, or assist in their own academic or professional development and so on. ${ }^{81}$

Legal research also includes the process of identifying the pertinent facts and legal issues related to a particular problem, finding and using relevant secondary sources, finding and using governing (appropriate and up to date) primary sources (law) and case law, analyzing the law as it relates to the legal issues and the facts of the case (application) and communicating the findings of the inquiry and analysis. ${ }^{82}$

On the other hand, the fact that the scope of the law is vast and its nature is ever-changing, and it is different from jurisdiction to jurisdiction, has made it impossible for anyone to know all the law about every topic and from every jurisdiction. ${ }^{83}$ In turn, these facts made legal research indispensable for lawyers to be able to stay abreast of the continual changes in the law while making proper (relevant) representations of the law to courts as it relates to their clients' cases. Accordingly, legal research is the process by which lawyers find the law, cut

\footnotetext{
${ }^{78}$ Dawn Watkins and Mandy Burton (edrs), Research Methods in Law (2nd ed., Routledge Publisher 2018) 7

79 S. N. Jain, 'Legal Research and Methodology' (1972) 14 (4) Journal of the Indian Law Institute 487, 500 <https://www.jstor.org/stable/43950155>; Terry Hutchinson and Nigel Duncan, 'Defining and Describing What We Do: Doctrinal Legal Research' (2012) $17 \quad$ (1) Deakin Law Review 83, 119 <https://doi.org/10.21153/dlr2012vol17no1art70> accessed 06 July 2021

${ }^{80}$ Stephen Elias, Legal Research How to Find \& Understand the Law (15th ed., Nolo Publishers 2009)

${ }^{81}$ Stephanie Delaney, Electronic Legal Research an Integrated Approach (2 ${ }^{\text {nd }}$ ed., Delmar Cengage Learning 2009)

${ }^{82}$ Edward A. Nolfi, Basic Legal Research for Paralegals, (2 ${ }^{\text {nd }}$ ed., Mcgrow Hill Iriwin Publishers 2008)

${ }^{83}$ Amy E. Sloan, Basic Legal Research, Tools and Strategies $\left(7^{\text {th }}\right.$ ed., Wolters Kluwer Publishers 2018)
} 
through it, and make effective arguments or solve legal problems. Therefore, lawyers that do not have the required skills of legal research are generally deemed incompetent. ${ }^{84}$

\subsection{Legal Research by Whom?}

Generally, anyone who is fit, curious, and interested to know something about the law and its operational facets could do legal research. So, legal research may be undertaken by a professional from another discipline (non-lawyers), a lawyer, paralegals, a law clerk, a law librarian, private investigators, law enforcement officials, writers, authors, and insurance company's employees, and other institutions. ${ }^{85}$

However, as a vast profession with complex and technical requirements of knowledge, skill, and experience, legal research is usually undertaken by persons with the required level of knowledge and skills in the law. These include Legislators, Judges, Lawyers, and Legal Academia (law professors and students). ${ }^{86}$

The above groups may undertake legal research for different reasons. For example, legislators do not legislate at random or simply because they are authorized to enact laws. Legislative enactments are made in response to some social purpose. Legislators have to decide the areas that are susceptible to legislative treatment. They have also to decide as to whether the proposed legislative measure improves the state of things or the existing social practice. Therefore, before legislation, all the required research shall be made by the legislature on the particular issues subjected to the legislation. ${ }^{87}$

Similarly, a judge, who acts as an adjudicator has to find the most relevant rules and principles of law from statutes, case laws, and the argument of the parties and apply them to the dispute brought before him. So a judge is expected to find the principles of law and to decide their applicability to the dispute. Such an exercise requires him or her to research the applicable rule and legal principles. Judges are also expected to give a reasoned decision on

\footnotetext{
${ }^{84}$ Carol M. Bast and Margie Hawkins, Foundations of Legal Research and Writing $\left(4^{\text {th }}\right.$ ed., Delmar, Cengage Learning 2010) 47

${ }^{85}$ Valerie J. Atkinson Brown, Legal Research via the Internet, (West Thomson Publishers 2001) 1, 96

${ }^{86}$ Frederick C Hicks, Materials and Methods of Legal Research (1942, Reprint 1959) 23, 31

${ }^{87}$ John C. Wahlke and Heinz Eulau (eds), Legislative Behavior-A Reader in Theory and Research (Free Press of Glencoe 1959) 413 <https://EconPapers.repec.org/RePEc:cup:apsrev:v:54:y:1960:i:02> accessed 06 July 2021
} 
how they use a 'rule' and arrive at a particular decision. It is via the underway of pertinent research, logical deduction, and legal reasoning that a Judge injects 'life' into 'law'. ${ }^{88}$

Practicing lawyers are the other groups that undertake legal research daily and as an exercise of their occupation. Research is an intuitive aspect of legal work. ${ }^{89}$ Legal research skills have been identified as a core skill for lawyers. Good legal research skills are a necessary step in attaining the ability to think like a lawyer and achieving valid legal reasoning outcomes. ${ }^{90}$

Practicing lawyers, as a professional, have to advise their clients and plead cases on their behalf in the court of law. They are also required to give legal opinions and advice on issues referred to them by clients. Therefore, it is as part of the requirement of the office and profession that lawyers need to undertake systematic research for 'finding' the law and thereby provide a solution to legal problems. ${ }^{91}$

By far, legal academicians are the ones that have a predominant association with legal research. For example, law professors are required by their universities to undertake legal research as a part of their professional commitment. ${ }^{92}$ In addition, law students must undertake various types of researches in fulfillment of their law degree. Therefore, strong legal research and writing skills are fundamental tools of legal scholarship. ${ }^{93}$ Doing legal research is an integral part of everyday teaching in academic institutions. Professors need to study the law and update themselves with relevant knowledge daily to serve as reliable sources of knowledge to their students. In addition, various intellectual challenges, academic reputation, and requirements of academic ranks and degrees are various reinforcements for academia to engage in legal research. ${ }^{94}$

\footnotetext{
${ }^{88}$ Douglas W. Vick, 'Interdisciplinary and the Discipline of Law' (2004) 31 (2) Journal of Law and Society 163 , 193 <https://doi.org/10.1111/j.1467-6478.2004.00286.x > accessed 06 July 2021

${ }^{89}$ Ibid

${ }^{90}$ Dawn Watkins and Mandy Burton (edrs), Research Methods in Law, (2 $2^{\text {nd }}$ edn., Routledge Publisher 2018) 8, 9

${ }^{91}$ S. N. Jain, supra note 79, 487, 488

${ }^{2}$ Sarah Valentine, 'Legal Research as a Fundamental Skill: A Lifeboat for Students and Law Schools, (2010) 39 (2) University of Baltimore Law 173, 226 <http://scholarworks.law.ubalt.edu/ublr/vol39/iss2/3> accessed 06 July 2021

93 J. C. Thomas, 'A Modest Programme for the Improvement of Law Teaching' (1978) 9(4) Victoria University of Wellington Law Review 405, 426 <https://heinonline.org/HOL/LandingPage?handles> accessed 06 July 2021

${ }_{94}^{4}$ T. Hutchinson, Researching and Writing in Law (2nd edn., Pyrmont, NSW: Lawbook Co., 2006) 7
} 


\section{The Impacts of AI on Research in the Legal Profession}

\subsection{The Positive Impacts of AI on Research in the Legal Profession}

Legal research in particular and the legal profession in general, are not immune from disruption by AI. Susskind has successfully predicted in 2013 that AI technologies will bring radical change in the legal profession in the next ten years. ${ }^{95}$ Susskind further argued that it is simply inconceivable that information technology will radically alter all corners of the economy and society and yet somehow legal work will be exempt from any change. ${ }^{96}$

Previously, because lawyers are highly trained and skilled professionals who identify the legal issues, gather the relevant facts and determine the likely outcome of a court decision to adjudicate a dispute by exercising judgment, using their experience and intuition, to assess the merits of a case to determine the best way to proceed, it was generally believed that lawyerly tasks could only be performed by highly-skilled professionals. ${ }^{97}$ However, recent developments in AI have challenged the traditional conceptions and proved that legal practice is not immune from AI. As a result, AI has and will cause a great disruption in legal research in particular and legal practice in general. ${ }^{98}$

Accordingly, recent developments in AI, such as natural-language processing and machine learning have challenged the traditional conceptions of human lawyer expertise. Various complex tasks that used to require human effort have been automated in ways that reduce cost and offer greater accuracy and precision, which is a good indicator that legal practice is not immune from these technological advances. That is why machine intelligence will cause a great disruption in the market for legal services regarding discovery, legal search, document generation, brief generation, and prediction of case outcomes. ${ }^{99}$

In this regard, AI provides celerity, simplicity, and effectiveness in solving a multitude of legal problems by researchers. More automation reduces transaction costs dramatically,

\footnotetext{
${ }^{95}$ Richard Susskind, Tomorrow's Lawyers: An Introduction to Your Future (2 $2^{\text {nd }}$ edn., Oxford University Press 2013)

96 Ibid

${ }^{97}$ Benjamin Alarie, Anthony Niblett, and Albert Yoon, (2017) 'How Artificial Intelligence Will Affect the Practice of Law' 1, 15 <http://dx.doi.org/10.2139/ssrn.3066816> accessed 06 July 2021

98 John O. McGinnis and Russell G. Pearce, supra note 22

${ }^{99} \mathrm{Ibid}$
} 
which enables the provision in reasonable conditions of services that were unprofitable, unaffordable, or unfeasible in other circumstances. ${ }^{100}$

AI can also perform automated tasks and adopt mass decisions efficiently. The use of AI is critical in legal research in terms of efficiency in searching, classifying, filtering, rating, and ranking issues, facts, ideas, laws, and so on. ${ }^{101}$

On the other hand, AI combined with computer systems is also capable of many other impressive feats that make the undertaking of legal research very easy. Such as recognizing and pointing out spelling errors and finding bad writing, and suggesting the rewriting of bad sentences. $^{102}$

Moreover, the weak version of AI is already serving as a large improvement on existing legal research tools such as Lexis and Westlaw, to assemble an array of relevant cases, suggest similarities and differences, and sketch arguments and counterarguments. On the strong version, however, in the future, AI will help lawyers or even judges, to engage in legal reasoning in researching the most relevant cases or laws to solve particular legal problems. ${ }^{103}$

AI is also a very useful tool for law and legal science in general. By applying knowledge to find a solution to legal problems, AI applications are assisting in legal reasoning. AI provides tools and techniques developed to solve specific problems in law in general. Legal science recognizes the usefulness of AI for legal reasoning and research. Legal reasoning is a general concept that refers to a process of forming and providing a justifiable answer to a particular legal question. ${ }^{104}$

For example, by searching databases of legal texts and identifying which cases are relevant to the respective ongoing judicial proceedings. ${ }^{105}$ AI tools significantly simplify legal research in the judiciary, as they can filter out irrelevant information. Besides, some AI expert systems can autonomously reason and provide specific answers by themselves to legal problems. ${ }^{106}$

Moreover, different AI applications are used in numerous contexts relevant to research in the legal profession. For example, legal reasoning is used to formalize legislation to identify

\footnotetext{
${ }^{100}$ Teresa Rodriguez, supra note 36, 302-314

${ }^{101}$ Cass R. Sunstein, 'Of Artifical Intelligence and Legal Reasoning' (2001) Uni. Chicago Public Law \& Legal Theory Working Papers No. 18, 1, 10 < http://nrs.harvard.edu/urn-3:HUL.InstRepos:12795544> acced. 06/2021 102 Ibid

103 Ibid

${ }^{104}$ Alzbeta Krausova, supra note 14, 55, 68

${ }^{105} \mathrm{Ibid}$

${ }^{106}$ Cass R. Sunstein, supra note 101, 29, 35
} 
ambiguities in the legal text and support the drafting of legislation or to model legal precedents. $^{107}$

Besides, not a few numbers of technologies assist lawyers in the due course of legal research, such as in identifying problematic clauses in contracts or planning a winning strategy in intellectual property lawsuits. For instance, another area of application for AI in the legal field is online dispute resolution, which is destined to solve disagreements between parties that entered into a contract via an electronic platform. ${ }^{108}$

The ability of AI to analyze vast amounts of data is also used, for example, in digital forensics. AI is also used for predictions, such as for determining which crime scenes will offer the best opportunity of recovering a forensic sample. ${ }^{109}$

Likewise, in human rights law practice and research, AI has offered an improved ability to monitor and document war crimes and human rights abuses. AI in the $21^{\text {st }}$ century has ushered in the golden age of surveillance by states, corporations, and non-state actors. Human rights groups, news organizations, and open-source investigators such as 'Bellingcat' and the 'Syrian Archive' access massive amounts of open-source data generated by billions of sensor platforms in the hands and pockets of people around the globe, which is very useful in human rights law research to fight war crimes. ${ }^{110}$

AI has also transformed another field important to human rights investigations, which is Forensic Anthropology. It has played a significant role in human rights abuse documentation since the 1980s, involving the examination of bones and other physical evidence to reconstruct the circumstances of death. In recent years, DNA sequencing has introduced a much greater degree of scientific accuracy and efficiency in forensic investigations. ${ }^{111}$

Moreover, in the future, AI is presumed to assist judges in the due course of adjudication. ${ }^{112}$ As eloquently described by Chief Justice John Roberts of the Supreme Court of the United States, in 2017, AI is assisting with courtroom fact-finding and decision-making, which is

\footnotetext{
${ }^{107}$ M. Sergot, T. Cory, P. Hammond, \& et al., 'Formalization of British Nationality Act' (1986) 2 Yearbook of Law Computers and Technology 40, 52 <http://heinonline.org/HOL/Page?handle=hein.> accessed 06 July 2021 108 D. Ben-Ari \& et al., supra note 15, 2, 55

${ }^{109}$ Faye Mitchell, 'The Use of Artificial Intelligence in Digital Forensics: An Introduction' (2010) 7 Digital Evidence and Electronic Signature Law Review, 35, 41<http://heinonline.org/HOL/Page?handle=hein.journals $>$ ${ }^{110}$ Steven Livingston and Mathias Risse, supra note 33, 141, 158

${ }^{111}$ Ibid

${ }^{112}$ Perel M. and Elkin-Koren N., 'Black Box Tinkering: Beyond Disclosure in Algorithmic Enforcement' (2017) 69 (1) Florida Law Review, 181, 221 http://heinonline.org/HOL/Page?handle accessed 06 July 2021
} 
putting a significant strain on how the judiciary goes about doing things. ${ }^{113}$ Moreover, the Chief Justice when asked whether he could foresee a day when AI would assist with courtroom fact-finding or judicial decision-making affirmed that 'It's a day that's here,' and $\mathrm{AI}$ is putting a significant strain on how the judiciary goes about doing things.' 114

Courts are also utilizing AI in making judicial decisions. Courts in the USA utilize advanced algorithms to assist in pretrial detainment of the accused. For example, the 'Public Safety Assessment tool is utilized in 29 American jurisdictions to determine the risk associated with defendants. ${ }^{115}$

On the other hand, acquiring legal representation to take and defend a case in court differs in various countries and can be a tedious, lengthy and costly process. Robots are also providing the possibility to have a positive impact in several aspects of the processes of the judicial system, as automation outperforms humans and increases productivity. ${ }^{116}$ Therefore, AI will have a positive impact in shortening the judicial process via automation and increased productivity. ${ }^{117}$ Studies show that the utilization of AI in courts could result in up to a $13 \%$ decline in lawyers' hours that would enable more rapid processing of cases in courts. ${ }^{118}$

Moreover, Legal AI is helping attorneys to become more efficient in research and serve a wider range of clients on a broader range of issues. If anything, legal AI is allowing lawyers to perform more work, with less effort, and more money. Accordingly, the only lawyers with anything to fear are those who refuse to embrace change for AI has the potential to break into almost every aspect of legal practice. ${ }^{119}$

Moreover, AI is influencing legal research and practice by making lawyers more efficient in their job, automating legal services, and updating the law itself. AI is challenging traditional legal concepts by forcing the law to adapt to new developments in technology. Concurrently, the law will be shaping developments in AI by imposing new standards, guidelines, as well as

\footnotetext{
${ }^{113}$ Thomas Julius Buocz, supra note 54

${ }^{114}$ Ibid

115 Taylor B. Schaefer, 'The Ethical Implications of Artificial Intelligence in the Law' (2019) 55 (11) Gonzaga University Law Review 217, 236 <https://gonzagalawreview.com/article/11470> accessed 06 July 2021

116 J. Manyika, M. Chui, M. Miremadi, J. Bughin, \& et al (2017), 'A Future that Works: Automation, Employment, and Productivity', Technical report, McKinsey Global Institute <http://www.mckinsey.com/global-themes/digital-disruption/> accessed 06 July 2021

117 Ibid

118 Dana Remus and Frank Levy, 'Can Robots Be Lawyers? Computers, Lawyers, and the Practice of Law' (2016) 1, 77 <http://dx.doi.org/10.2139/ssrn.2701092> accessed 06 July 2021

119 Staci Zaretsky, 'Trendspotting?Major U.K. Client Refuses To Pay Junior Big law Attorneys' (2017) Above the Law 1 <https://abovethelaw.com/2017/03/trendspotting> accessed 06 July 2021
} 
limitations on developments in various AI application domains. ${ }^{120}$ In this regard, for example, AI is influencing the traditional big firm model where associates work for 2,300 hours a year. $^{121}$

Currently, most of the work of associates is geared towards legal research and due diligence that is highly amenable to be assisted by AI tools, which made modern lawyers more effective than the traditional approach. ${ }^{122}$ That is why emerging legal tech companies allow these associates to use AI capabilities to identify legal authorities relevant to particular questions, which made them more effective than the traditional, labor-intensive approach utilized by most big firms today. Accordingly, researches show that law firms that use AI tools: (1) have better information retrieval quality, (2) are intuitive to use requiring little training, and (3) will drastically cut working hours. This enabled firms to abstain from hiring many associates and spend less time on research, which freed associates for other substantive activities by automating legal grunt work. ${ }^{123}$

Currently, due to the advent of AI support, firms will no longer need to hire many associates to sift through contracts and conduct legal research. The use of AI tools is helping to maximize the efficiency of each research project, forcing firms to either cut down on hiring or put their associates to better use. Furthermore, with legal grunt work becoming automated, associates will be free to engage in more substantive work at earlier stages in their careers. ${ }^{124}$

Similarly, it is evident that the Big Law Firm model will disappear soon due to developments in legal AI. This is because AI will create universal access to services that previously could only be accomplished by teams of highly educated attorneys. ${ }^{125}$ Moreover, with the advent of more efficient research tools, smaller firms are competing with larger firms in providing cheaper services. Such competition could force larger firms to restructure their business model that charged clients exorbitant prices. ${ }^{126}$

On the contrary, there is also a possibility that big firms, with their resources and profit margins, have more chances to gain access to this disruptive technology at an earlier stage

\footnotetext{
${ }^{120}$ David Houlihan, 'Ross Intelligence: Artificial Intelligence in Legal Research' (2017) Blue Hill Research $<$ http://bluehillresearch.com/ross-intelligence-and-artificial-intelligence> accessed 06 July 2021

121 Ibid

122 Ibid

${ }^{123}$ Sean Semmler \& Zeeve Rose, supra note 39

${ }^{124}$ Ibid

125 Ibid

126 Ibid
} 
than smaller firms do, which enables them to attract new clients while retaining their old clientele, which will be discouraging for smaller firms to join the market. ${ }^{127}$

Hence, the use of AI in legal research and practice is inevitable due to its competitive, comparative, and differential advantages. AI tools allow law firms to reduce the labor hours required for research and spend more time on high-value legal matters, which enables the firm to produce cheaper services while attracting more customers thereby creating a competitive advantage. The use of AI tools is also enabling firms to attract both curious clients and top-talent lawyers. ${ }^{128}$

Studies further suggest that the adoption of AI tools in legal research provides significant advantages. For example, in 2017, 'Blue Hill Research' prepared a Report on AI in legal research that participated in a research panel of 16 lawyers and compared the impact of traditional legal research tools with the use of ROSS. ${ }^{129}$ The results suggested a significant reduction in research time of $30.3 \%$ and a $42.9 \%$ increase in retrieving relevant authorities. ${ }^{130}$

On the other hand, even on an individual level, AI is enabling lawyers to do more work at a given time, which has increased their efficiency. With the ability to work efficiently, lawyers are less tethered to work in large firms and still can perform capably. Efficiency will also empower lawyers to broaden their areas of specialization. At present, lawyers are using AI tools to maintain areas of expertise and develop new ones. ${ }^{131}$

On the other hand, due to the fierce competition and cheap services brought by the advent of AI clients are becoming less willing to pay big prices for legal research. Clients are starting to demand fixed fees for work that was traditionally billed by the hour, which is forcing firms to lower their prices. ${ }^{132}$

Additionally, with the increased availability of AI tools, client expectations could change in that they become less willing to pay six-figure bills for legal research by lawyers. Currently, Clients are starting to demand fixed fees for work that was traditionally billed by the hour and

\footnotetext{
127 Ibid

${ }^{128}$ Katherine Medianik, 'Artificially Intelligent Lawyers Updating the Model Rules of Professional Conduct in Accordance with the Technological Era' 39 Cardozo Law Review, 1498, 1530 <http://cardozolawreview.com/wp-content/uploads/2018/07/MEDIANIK.39.4.pdf> accessed 06 July 2021

${ }^{129}$ Andrew Arruda \& Matt Scherer, 'Artificial Intelligence: Will it Replace Lawyers? ROSS Intelligence and Artificial Intelligence in Legal Research’ (2017) Blue Hill Benchmark Report Number A0280 2, 10

${ }^{130}$ Ibid

131 Albert H. Yoon, 'Cognitive Computing and the Future of the Legal Profession' (2016) 66 University of Toronto Law Journal 456, 471 〈http://dx.doi.org/10.3138/UTLJ.4005> accessed 06 July 2021

${ }^{132}$ Staci Zaretsky, supra note 119
} 
it is also common for clients to demand that associate work not be included in their bill. Clients are beginning to expect more value for their money. As a result, with these changing client expectations, firms must lower their prices and adapt, or otherwise, they will lose huge amounts of business. ${ }^{133}$

On the other hand, AI also increased the availability of legal services to consumers without hiring an attorney. AI by taking over some lawyer activities has enhanced access to justice and enabling mass-scale representation. For example, in April 2016, the 'DoNotPay' robot had helped people overturn 160,000 of 250,000 parking tickets. Since its launch, this robot scored a success rate of $64 \%$ appealing over $\$ 4$ million. ${ }^{134}$

Similarly, AI has also significantly transformed the ability to store and access legal information and it creates full access to legal information, which is a core skill of legal research by lawyers. It has extensively transformed how laws were maintained, learned, and researched from analog (codified and published) to digital (soft copy). ${ }^{135}$ It has transformed how laws are maintained, learned, and researched from analog to digital with the advent of computer-assisted legal research in the 1970s. ${ }^{136}$

Moreover, AI also created the possibility to access all the needed legal information from anywhere in the world. ${ }^{137}$ Due to the advent of AI, lawyers today can conduct most of their legal research online. ${ }^{138}$

Accordingly, lawyers today conduct most of their legal research online via assistance from data providers such as Westlaw, Lexis, or Bloomberg or publicly available resources such as Justia (United States) or CanLII (Canada) or general search engines such as Google. Updated sources of the law, such as judicial opinions, court decisions, legislation, regulations are all available online and can be accessed online from anywhere in the world. This contributed a great deal to the development of cross-border legal research and the study of the law. ${ }^{139}$

\footnotetext{
${ }^{133}$ Ibid

134 Samuel Gibbs, 'Chatbot Lawyer Overturns 160,000 Parking Tickets in London and New York', (2016) The Guardian 〈https://www.theguardian.com/technology/2016/jun/28> accessed 06 July 2021

135 James A. Sprowl, 'Computer-Assisted Legal Research: Westlaw and Lexis' (1976) 62 American Bar Association Journal 320, 323 <https://www.jstor.org/stable/25727555> accessed 06 July 2021

${ }^{136}$ Ibid

137 James L. Hoover, 'Legal Scholarship and the Electronic Revolution' (1991) 83 Law Library J. 643

${ }^{138}$ Benjamin Alarie \& et al., supra note 97,7

139 Ibid
} 
Accordingly, Lexis and Westlaw have continued to improve legal research, resulting in more user-friendly access mechanisms, comprehensive databases, and innovative electronic research methods. ${ }^{140}$ For example, currently, LexisNexis had 15,000 databases and over 9 million subscribers worldwide and Westlaw is the primary online legal research service in the USA, UK, and Australia with more than 40,000 databases of legal information. ${ }^{141}$

Legal AI also resulted in the advent of computational legal research tools that can be used to access information with greater speed, lower cost, and higher accuracy. For example, ediscovery has replaced traditional discovery and made it possible to conduct accurate discovery with a fraction of the time, expense, and need for lawyers. This made lawyers spend less percent of their time on basic document review and become more productive. ${ }^{142}$

Legal AI has also resulted in predictive tools that are vital for legal research in assessing the merits of a case. The predictive power of AI tools is transforming the way lawyers approach research in litigation. For lawyers, evaluating how a litigant's current case maps onto the existing set of court decisions can present several challenges. For instance, legal issues are usually shaped by hundreds of judicial decisions (precedents), which will make it insurmountable for lawyers to evaluate all such decisions in the past. In this regard, AI tools are helping to overcome the challenge by providing a more objective prediction of the likely outcome of a particular case. ${ }^{143}$ For example, look at existing studies that used AI to predict up to $70 \%$ success rate of the decisions of the European Court of Human Rights in 2016. ${ }^{144}$ In addition, AI has been used to predict a Supreme Court Ruling in the USA, which accurately predicted over $70 \%$ of decisions. ${ }^{145}$

On the other hand, Susskind suggested that, in the future, in addition to forcing lawyers to take on new roles within the realm of legal practice, AI would result in the creation of new

\footnotetext{
${ }^{140}$ Frank Y., Liu Joel Fishman, Dittakavi N. Rao, and Tsegaye Beru, (2008) Pennsylvania Legal Research Handbook, ALM Media, LLC

${ }^{141}$ John O. McGinnis and Russell G. Pearce, supra note 22; Hannah Augur, 'AI Is the Future of Law And Lawyers Know It', (2016) Dataconomy <http://www.dataconomy.com/ai-future-law-lawyers-know>

${ }^{142}$ Daniel Martin Katz, 'Quantitative Legal Prediction-or-How I Learned to Stop Worrying and Start Preparing for the Data-Driven Future of the Legal Services Industry' (2013) 62 Emory Law Journal 909,936 $<$ https://ssrn.com/abstract=2187752> accessed 06 July 2021

${ }^{143}$ Benjamin Alarie \& et al., supra note 97

${ }^{144}$ Aletras N, Tsarapatsanis D, Preoţiuc-Pietro \& et al., 'Predicting judicial decisions of the European Court of Human Rights: a Natural Language Processing perspective' (2016) 2 Peer Journal of Computer Science 93 <https://doi.org/10.7717/peerj-cs.93> accessed 06 July 2021

145 Katz DM., Bommarito MJ. \& Blackman J., 'A General Approach for Predicting the Behaviour of the Supreme Court of the United States' (2017) 12 (4) PLoS ONE 1 <https://doi.org/10.1371/journal.pone.0174698> accessed 06 July2021
} 
types of jobs for lawyers such as Legal Knowledge Engineer, Legal Technologist, Legal Process Analyst, and so on. ${ }^{146}$

Similarly, it is believed that due to the use of AI tools the roles of lawyers will shift rather than disappear and become more interactive with technology. Hence, there is a consensus that human guidance combined with the technical acuity of AI could produce highly successful outcomes in legal practice. ${ }^{147}$ For example, in the case of e-discovery, though lawyers may not sift through the documents themselves, they remain indispensable to the e-discovery process. ${ }^{148}$

In the future, it is evident that AI will continue to learn and develop and become a commonly used tool in legal research and practice. It is having considered the future unavoidable impact of AI that in 2017 the English House of Lords established a selected committee to consider the economic, legal, and social implications of the advances in AI. ${ }^{149}$ Similarly, on the European level, 25 states signed the Declaration of Cooperation on Artificial Intelligence in 2017. ${ }^{150}$

\subsection{Legal AI tools Impacting Research in the Legal Profession}

This section discusses the typical examples of AI tools that are currently in use and influencing research in the legal profession. Accordingly, the following AI tools are typical:

4.2.1 Legal Text Analytics Tools: These AI tools use algorithms to extract meaning from court decisions or laws. ${ }^{151}$ Legal text analytics includes (1) Argument mining which is used for the discovery of arguments from legal archives. ${ }^{152}$ (2) Legal network diagrams tools that provide graphic depictions of the relations between legal objects. ${ }^{153}$ The following are typical examples of Legal Text Analysis AI tools:

\footnotetext{
146 Alyson Carrel, 'Legal Intelligence Through Artificial Intelligence Requires Emotional Intelligence: A New Competency Model for the 21st Century Legal Professional' (2019) 35 Ga. St. U. L. Rev. <https://ssrn.com/abstract=3425333>_accessed 06 July2021

${ }^{147}$ Eric Brynjolfsson and Andrew McAfee, The Second Machine Age (W. Norton \& Company Inc. 2014) 188

${ }^{148}$ Richard Susskind, Tomorrow's Lawyers: An Introduction to Your Future (Oxford University Press 2013$) 111$

${ }^{149}$ Nancy Namisi Siboe, 'Herald! The Era of Legal Artificial Intelligence in Legal Practice' (2019) The Law Society of Kenya Advocates Magazine (Annual Conference Edition) 1, 20

150 The EU Declaration on Cooperation on Artificial Intelligence (2018); The European Parliament Resolution on Civil Law Rules on Robotics (2015/2103(INL)) (2018/C 252/25) 2017

${ }^{151}$ Kevin D Ashley, Artificial Intelligence and Legal Analytics: New Tools for Law Practice in the Digital Age (Cambridge University Press 2017) 123

152 Tania Sourdin, 'Justice and Technological Innovation' (2015) 25 (2) Journal of Judicial Administration 96, 105 <https://goo.gl/hxbXri > accessed 06 July 2021

${ }^{153}$ Kevin D Ashley, supra note 151, for a more complete description of these processes and systems
} 
- 'Ravel', in 2017, scanned and made all case laws in the USA accessible in visual maps with citations.

- 'CARA', outputs or summarizes additional relevant cases to cite in support of legal arguments.

- 'Casetext' and 'Fastcase' provide a citation network of relations among cases or statutes. ${ }^{154}$

- 'Luminance', can model how solicitors think to draw out key findings in a case. The tool is award-winning and currently deployed by 26 organizations in 12 countries. ${ }^{155}$

4.2.2 Legal Question and Answer (Advisory) tools: are tools that are used to search large text collections to answer a user's legal question. The following are typical examples:

- 'ROSS' can accept legal questions and outputs answers, citations, suggested readings, and updates in order of relevance. ${ }^{156}$ 'ROSS' can also draft legal memorandums. ${ }^{157}$

- 'Lexis Answers', can analyze millions of documents to create a 'Lexis Answer Card' with citation. ${ }^{158}$

- 'Watson Debater', can thoroughly discuss any topic and suggests persuasive arguments and precedents on legal matters. ${ }^{159}$

- 'CCLIPS' is designed to retrieve relevant cases and statutes from a highly integrated database containing, the Civil Code of Louisiana. ${ }^{160}$

4.2.3 Legal Prediction Tools: these are AI tools that can predict the outcomes of a court case by reference to earlier decisions. The following are typical examples:

\footnotetext{
${ }^{154}$ Mary Ann Neary and Sherry Xin Chen, ‘Artificial Intelligence: Legal Research and Law Librarians' (2017) AALL Spectrum 21(5) 16, 20 <http://lawdigitalcommons.bc.edu/lsfp> accessed 06 July 2021

155 Horizon, 'Artificial Intelligence (AI) and the Legal Profession' (2018) The Law Society of England and Wales, Report, 6 <Artificial Intelligence (AI) and the Legal Profession-Horizon report> accesd. 06 July 2021

${ }^{156}$ Sean Semmler \& Zeeve Rose, supra note 39, 85, 99 https://scholarship.law.duke.edu/dltr/vol16/iss1/3; ROSS Intelligence, 'ROSS Intelligence announces partnership with BakerHostetler' (2016) 1 <http://www.prnewswire.com/news-releases/ross-intelligence-announces > accessed 06 July 2021

157 Andrew Arruda, 'An Ethical Obligation to Use AI: An Examination of the Use of Artificial Intelligence in Law and the Model Rules of Professional Responsibility' (2017) 40 (3) American Journal of Trial Advocacy 443, 458 <https://heinonline.org/hol-cgi-bin/get_pdf.cgi?handle=hein.> accessed 06 July 2021

158 Taylor B. Schaefer, supra note 115, 222, 234

${ }^{159}$ Daniel Ben-Ari \& et al, supra note 15

160 Cary G. Debessonet \& George R. Cross, 'Artificial Intelligence Application in the Law: CCLIPS, a Computer Program That Processes Legal Information’ (1986) < http://dx.doi.org/doi:10.15779/Z382Q13>
} 
- 'Scotus', could correctly forecast $70 \%$ of case law outcomes. ${ }^{161}$

- 'Lex Machina', can predict with $64 \%$ accuracy outcomes of intellectual property cases. ${ }^{162}$

- 'Motion Kickstarter', enables attorneys to view granted or denied motions in courts. ${ }^{163}$

- 'CaseCruncher Alpha', is a tool that can predict judicial decisions with high accuracy. ${ }^{164}$ In 2017, 'CaseCruncher Alpha' was in a contest with more than 100 lawyers in London. The Case Cruncher won by getting an accuracy rate of $86.6 \%$, compared with $66.3 \%$ for the lawyers. ${ }^{165}$

- 'Blue J Legal', can predict how courts would decide legal questions based on a given set of facts by using machine learning. ${ }^{166}$

4.2.4 Contract Review and Analysis tools: are AI tools that can acquire knowledge and use it at the 'clause level' to review a document. The following are typical examples:

- 'LawGeex', can read and summarize contracts with an average accuracy of 94\% saving up to $80 \%$ of the time. ${ }^{167}$

- 'ThoughtRiver', can scan contracts and presents the information in an online dashboard. ${ }^{168}$

- 'Legal Robot', can check, analyze, and spot problems in contracts before users sign on them. ${ }^{169}$

- 'Beagle', is designed for non-professional users who need to review and manage contracts by themselves. ${ }^{170}$

\footnotetext{
${ }^{161}$ Michael Mills, 'Artificial Intelligence in Law: the State of Play' (2016) 3, 6

162 John R. Allison \& et al., 'Understanding the Realities of Modern Patent Litigation' (2014) 92 Texas Law Review 1769, 1773 <http://texaslawreview.org/wp-content/uploads/2015/08/AllisonEtAl-92-7.pdf>

${ }^{163}$ Ibid

${ }^{164}$ Thomas Julius Buocz, supra note 54

${ }^{165}$ Nancy Namisi Siboe, supra note 149; Jason Tashea, 'Artificial Intelligence Software Outperforms Lawyers (without subject matter expertise) in Matchup' (2017) ABA Journal; Nikolaos Aletras \& et al., 'Predicting Judicial Decisions of the European Court of Human Rights: A Natural Language Processing Perspective' (2016) 2 Peer J Computer Science 92 〈https://doi.org/10.7717/peerj-cs.93〉 accessed 06 July 2021

${ }^{166}$ Benjamin Alarie \& et al., supra note 97, 231, <http://dx.doi.org/10.2139/ssrn.2855977> accesd. 06 July 2021

${ }^{167}$ Sean Semmler \& Zeeve Rose, supra note 39, 88; M. Simon, A. Lindsay, L. Sosa \& P. Comparato 'Lola v. Skadden and the Automation of the Legal Profession' (2018) 20 Yale J.L. \& Tech., 234

168 Ibid

169 'Legal Robot' (2016) 1<http://www.legalrobot.com> accessed 06 July2021

170 'How It Helps, BEAGLE' (2016) < http://beagle.ai/>; M. Simon \& et al., supra note 167, 89
} 
- 'COIN', can correctly review and interpret commercial loan agreements cutting down on attorneys' hours by approximately 360,000 hours per year. ${ }^{171}$

- 'HYPO', can assist in all aspects of legal research and is found to be not so different from the performance by actual judges. ${ }^{172}$

- Other similar tools are 'Relativity', 'Kira Systems', 'Modus', 'OpenText', 'kCura', and others. ${ }^{173}$

4.2.5 E-discovery (Technology Assisted Review) tools: are software that helps legal teams with document management and review. ${ }^{174}$ For example, in litigation, e-discovery enables to automate, review, and analyze large collections of electronic information to identify the relevant laws. ${ }^{175}$ TAR has been recognized and used in courts in the USA, England, and Ireland since 2012. ${ }^{176}$ Besides, TAR was approved by the Supreme Court of Victoria in 2016, in Australia, in McConnell Dowell Constructors $v$ Santam, as an accepted method of conducting a reasonable search. ${ }^{177}$ Researches show that TAR can yield more accurate results than an exhaustive manual review with much lower effort. ${ }^{178}$

There are also adequate studies that show the benefits of e-discovery, which can amount to saving $70 \%$ or more time. ${ }^{179}$ A recent study shows that most Fortune 1000 companies spend more than $\$ 5$ million each year on e-Discovery and with $70 \%$ of the costs on reviewing physical documents. Through proper use of AI tools, lawyers can significantly reduce the costs of document review. ${ }^{180}$

\footnotetext{
171 Taylor B. Schaefer, supra note 115, 222, 234

${ }^{172}$ Cass R. Sunstein, supra note 101, 29, 35

${ }^{173}$ Daniel Ben-Ari \& et al, supra note 15, 13, 14

${ }^{174}$ Paul Hellyer, 'Assessing the Influence of Computer-Assisted Legal Research: A Study of California Supreme Court Opinions' (2005) < https://scholarship.law.wm.edu/libpubs/5> accessed 06 July 2021

${ }^{175}$ Bas Boris Visser, 'Artificial Intelligence and the Future for Legal Services' (2017) Clifford Chance, 1, 8 $<$ https://www.cliffordchance.com/briefings/2017/11/AIhtml> accessed 06 July 2021

${ }^{176}$ See also Moore vs Publicis Groupe, 287 F.R.D. 182182 (S.D.N.Y. 2012; Irish Bank Resolution Corporation Limited v Quinn [2015] IEHC 175; see also, Pyrrho Investments Ltd v MWB Property Ltd [2016] EWHC 256 (Ch).

${ }^{177}$ See also, McConnell Dowell Constructors (Aust) Pty Ltd v Santam Ltd and Others (No 1) [2016] VSC 734 (Vickery J) ("McConnell Dowell")

${ }^{178}$ Maura R. Grossman \& Gordon V. Cormack, 'Technology-Assisted Review in E-Discovery Can Be More Effective and More Efficient Than Exhaustive Manual Review' (2011), 17(3) Richmond Journal of Law \& Technology 1, $49<$ http://scholarship.richmond.edu/jolt/vol17/iss $3 / 5>$ accessed 06 July 2021

${ }^{179}$ Anne Kershaw \& Joe Howie, 'Crash or Soar: Will The Legal Community Accept Predictive Coding?' (2010) Law Technology News <https://perma.cc/84KN-4BQD>; Chris Dale, 'Having The Acuity to Determine Relevance with Predictive Coding' (2010) E-Disclosure Information Project 〈https://perma.cc/727C-CWVT> accessed 06 July 2021

${ }^{180} \mathrm{Ibid}$
} 
4.2.6 Drafting Tools: are AI tools that offer an automated document assembly system. The following are typical examples:

- 'Clifford Chance Dr@ft', allows clients to generate a tailor-made legal document. ${ }^{181}$ It saves time and resources, improves the quality of legal documents. ${ }^{182}$

- Other similar tools are 'Desktop Lawyer', 'Legal Zoom' and 'Rocket Lawyer' ${ }^{183}$

- In Australia, 'LegalVision', 'LawPath' and ‘ClickLaw' offer similar services. ${ }^{184}$

4.2.7 Citation Tools: These are tools that provide citation format and support in legal research. For example, 'KeyCite' is now a well-established citation system parallel to the online Shepard's Citations that provides detailed citations of legal sources. ${ }^{185}$

\subsection{The Negative Impacts of AI on Research in the Legal Profession}

Accordingly, studies show that AI cannot read legal texts like lawyers can; applications can only extract some meaning from legal texts; machine language yields answers but not explanations; AI cannot usually explain its answers to legal questions; Question and Answer systems do not understand legal reasoning; ${ }^{186}$ a tool cannot also reason about how different circumstances would affect its answers, and the majority of the AI tools also cannot work with total independence from human support. ${ }^{187}$

On the other hand, according to Susskind, several problems and obstacles have been faced and will continue to confront the development of legal AI such as the lack of knowledge engineers, the lack of domain experts, the lack of existing methodology to be used by designers for the development of expert systems in the legal area, the lack of adequate AI tools, difficulties in quality control of legal AI systems, and the presence of huge concerns on the legal implications of AI tools. ${ }^{188}$

\footnotetext{
181 Ibid

182 Ibid

${ }^{183}$ Kathryn D. Betts \& Kyle R. Jaep, 'The Dawn of Fully Automated Contract Drafting: Machine Learning Breathes New Life into a Decades-Old Promise' (2017) 15 Duke Law \& Technology Review 216, 218 <https://scholarship.law.duke.edu/dltr/vol15/iss1/11/> accessed 06 July 2021

${ }^{184}$ Michael Legg and Felicity Bell, supra note 58, 14, 20

185 Ibid

186 John Searle, 'Can Computers Think?' in David J. Chalmers (ed), Philosophy of Mind: Classical and Contemporary Readings (Oxford University Press 2002) 669, 671.

${ }^{187}$ Keven Ashley, supra note 151

${ }^{188}$ Richard E. Susskind, 'Artificial Intelligence, Expert Systems and Law', (1990) 5 Denning Law Journal 105
} 
Moreover, AI is also blamed for other disruptive features in the legal profession such as the problems of complexity, the worrisome increasing autonomy of AI systems over time, the problem of opacity in decision making of AI systems, and the technological vulnerability of AI systems because they are highly dependent on collected data, which may be insufficient, inaccurate, or biased. ${ }^{189}$ Moreover, the fact that AI systems are exposed to cyber-security attacks or breaches is a major challenge to the development of legal AI. ${ }^{190}$

There is also a legitimate concern regarding who is going to be responsible for the mistakes of AI tools that are just a piece of machinery or a program, the developer or the users. Therefore, not a few numbers of scholars suggest that the crucial need to regulate and hold someone accountable shall be treated by the law. ${ }^{191}$

On the other hand, there are also other major noticed constraints to integrate AI into the legal profession such as technical constraints, the problem of the complexity of legal reasoning, the lack of adequate market for legal AI (economic constraints), and the significantly slow culture of legal practice (cultural constraints) to integrate with AI. ${ }^{192}$

Moreover, studies show the likely negative impacts of legal AI technologies on the legal profession in general such as high rate of unemployment ${ }^{193}$, insecurities related to data privacy, ethics, and dishonest use of data, and the unwanted creation of a super-intelligent AI, which is also called the 'Singularity problem'. 194

On the other hand, there is a justifiable argument that judges should not delegate judgments or a specific administrative task to an AI assistant and judges need to stay in full control. ${ }^{195}$ Moreover, AI is in principle deemed incapable of adequately engaging in legal (analogical) reasoning or evaluative judgments, which is considered a serious challenge to legal AI in the long term. ${ }^{196}$ Moreover, the fact that many judgments involve an element of discretion, which is not the case for computer programs that operate based on the logic of input and output

\footnotetext{
189 Teresa Rodriguez de las Heras Ballell, supra note 36

${ }^{190}$ Richard E. Susskind, supra note 188

${ }^{191}$ Sean Semmler \& Zeeve Rose, supra note 39

192 Mark McKamey, 'Legal Technology: Artificial Intelligence and the Future of Law Practice' (2017) 22

Appeal: Rev. Current L. \& L. Reform, 45

<https://journals.uvic.ca/index.php/appeal/article/download/16750/7104> accessed 06 July 2021

193 Taylor B. Schaefer, supra note 115, Deloitte's research shows that AI would result in the automation of $39 \%$ of the jobs in the legal field in the future.

${ }^{194}$ WIPO Technology Trends, (2019) 'Artificial Intelligence’ 1, 15

195 Thomas Julius Buocz, supra note 54

${ }^{196}$ Cass R. Sunstein, supra note 101, 29, 35
} 
exacerbated the problem of integration of AI with the legal profession. ${ }^{197}$ Finally, there is also a convincing argument that $\mathrm{AI}$ is not immune from the bias and prejudice of its creators as a result; it cannot be always trusted to be fair and neutral. ${ }^{198}$

\section{Conclusion}

In this essay, an effort was made to enumerate and discuss the future impacts of AI on legal research in the legal profession. As some scholars try to portray, the law is neither rocket science nor entirely repugnant of technology. Hence, legal research in particular and legal practice, in general, is amenable to and influenced by AI both positively and negatively. Moreover, it is evident from the study that the positive impacts of AI are far greater than its negative externalities, which are usually temporary and related to the disruptive effects of technology on the legal profession.

It should also be emphasized that legal research, which includes multifaceted activities is a core lawyering skill and an integral part of legal practice. All types of legal professionals (judges, lawyers, legislators, and academicians) must undertake legal research in due course of delivering various types of legal services and the quality of their research determines the quality of the services they provide to clients. As a result, when one tries to assess the impact of AI on legal research, s/he is also implicitly assessing such an impact on the entirety of legal practice to which the research is an integral part.

Only some decades ago legal research was an activity that can only be done by lawyers in a physical library. At present, due to advances in "Weak AI", many of the activities that constitute legal research are being done by AI tools with minimal human support, which resulted in monumental efficiency (in time, energy, resources) in the underway of legal research and legal grunt work.

At present, there are up to 5000 legal tech startups throughout the world who are automating some type of legal work, which is a good reminder for tomorrow's lawyers that they will need to familiarize themselves with how to research the law using such AI tools in addition to

\footnotetext{
197 Justice Melissa Perry, 'iDecide: Administrative Decision-Making in the Digital World' (2017) 91 Australian Law Journal, 29, 30 <http://www.austlii.edu.au/au/journals/FedJSchol/2019/3.html> accessed 06 July 2021 198 Mirjana Stankovic, Ravi Gupta, Bertrand A., \& et al., 'Exploring Legal, Ethical and Policy Implications of Artificial Intelligence' (2017) Law, Justice, and Development White Paper 1, 15 <https://globalforumljd.com/resources/> accessed 06 July 2021
} 
possessing a working knowledge of the law. The same holds for law schools that should consider including legal AI courses into their academic curriculums.

Currently, AI tools can do almost all types of activities related to legal research such as Legal Text Analytics, Legal Question and Answer (Advisory), Legal Outcome Prediction, Contract Review, and Due Diligence, E-discovery (Technology Assisted Review), Document Drafting, Citation Tools, and so on.

In the future, with the advent of Strong AI, which has a massive computational and analytical capacity of a vast amount of data and brute force of processing, the impact of AI on legal research will be far greater than mere automation (pre-programmed decision making). With such a leap in computational capacity and advances in algorithmic reasoning, AI tools are expected to develop the capability to deliver efficient legal services by autonomously undertaking legal research that is destined to sort out legal problems that will require human empathy, judgment, and creativity and thereby satisfy client expectations.

\section{Competing interests}

The author declares that there are no competing interests.

\section{References}

\section{Books}

A. Edward N, Basic Legal Research for Paralegals (2nd edn., Iriwin Publishers 2008)

Atkinson V. Brown, Legal Research via the Internet (West Thomson Publishers 2001)

C. F. Hicks, Materials and Methods of Legal Research (3rd edn., Lawyers Cooperative Pub. Co 1942)

C. J. Wahlke \& Heinz Eulau, Legislative Behavior-A Reader in Theory and Research (Free Press of Glencoe 1959)

D. K. Ashley, Artificial Intelligence and Legal Analytics: New Tools for Law Practice in the Digital Age, Cambridge University Press (2017)

E. A. Sloan, Basic Legal Research, Tools, and Strategies (7th edn., Wolters Kluwer 2018)

Elias S, Legal Research How to Find \& Understand the Law (15th edn., Nolo Publishers 2009) 
Hutchinson T, Researching and Writing in Law (2nd edn., Pyrmont NSW 2006)

K. Ashley, Artificial Intelligence and Legal Analytics: New Tools for Law Practice in the Digital Age, Cambridge University Press (2017)

M. C. Bast \& Hawkins M, Foundations of Legal Research and Writing (4th edn., Delmar Cengage Learning 2010)

McConville M, \& Hong W. Chui, Research Methods for Law (Edinburgh University Press 2007)

M. P. Bakshi, Legal Research and Law Reform, in S. K. Verma \& M Afzal Wani, Legal Research and Methodology (2nd edn, Indian Law Institute 2001)

Salter M. and Mason J, Writing Law Dissertations, an Introduction and Guide to the Conduct of Legal Research (Pearson Longman Publishers 2007)

Searle J, Can Computers Think? In David J. Chalmers (ed), Philosophy of Mind: Classical and Contemporary Readings (Oxford University Press 2002)

Susskind R, Tomorrow's Lawyers: An Introduction to Your Future (Oxford University Press, 2013)

Watkins D. \& Burton M, Research Methods in Law (2nd edn., Routledge Publisher 2018)

Y. Frank, Fishman L., Rao D. \& Beru T, Pennsylvania Legal Research Handbook (ALM Media LLC 2008)

\section{Journals Articles}

A. J. Sprowl, 'Computer-Assisted Legal Research: Westlaw and Lexis', (1976) 62 American Bar Association Journal

Alarie B, Niblett A, \& H. A Yoon, 'Using Machine Learning to Predict Outcomes in Tax Law', (2016) 58 Canadian Business Law Journal

Alarie B, Niblett A \& Yoon A, 'How Artificial Intelligence Will Affect the Practice of Law', (2017) SSRN 1

Ann M. Neary \& Xin S. Chen, 'Artificial Intelligence: Legal Research and Law Librarians' (2017) 21 (5) AALL Spectrum 
Arruda A, ‘Artificial Intelligence Systems and the Law', (2016) Peer-To-Peer Magazine

Arruda A, 'an Ethical Obligation to Use Artificial Intelligence: An Examination of the Use of Artificial Intelligence in Law and the Model Rules of Professional Responsibility', (2017) 40

(3) American Journal of Trial Advocacy

Arruda A. \& Matt Scherer, 'Artificial Intelligence: Will it Replace Lawyers? ROSS Intelligence and Artificial Intelligence in Legal Research', (2017) Blue Hill Benchmark Report Number A0280

Ben-Ari D, Frish Y, Lazovski A, 'Artificial Intelligence in the Practice of Law: An Analysis and Proof of Concept Experiment' (2017) 23 (3) Rich. J. of Law \& Technology

Brynjolfsson E. \& McAfee A, The Second Machine Age (W. W. Norton \& Company Inc. 2014)

B. T. Schaefer, 'The Ethical Implications of Artificial Intelligence in the Law', (2019) 55 (1) Gonzaga University Law Review

Carrel A, 'Legal Intelligence through Artificial Intelligence Requires Emotional Intelligence: A New Competency Model for the 21st Century Legal Professional', (2019) 35 (4) Georgia State University Law Review

C. J. Thomas, 'A Modest Programme for the Improvement of Law Teaching', (1978) 9 (4) Victoria University of Wellington Law Review

Dana R \& Frank L. S., 'Can Robots Be Lawyers? Computers, Lawyers, and the Practice of Law', (2016) SSRN

D. K. Betts and R. K. Jaep, 'The Dawn of Fully Automated Contract Drafting: Machine Learning Breathes New Life into a Decades-old Promise', (2017) 15 Duke Law \& Technology Review

DM Katz, MJ Bommarito, \& J. Blackman, 'A General Approach for Predicting the Behaviour of the Supreme Court of the United States', (2017) 12 (4) PLoS One e0174698

E. R. Susskind, ‘Artificial Intelligence, Expert Systems, and Law', (1990) 5 (1) Denning Law Journal 
G. C. Debessonet \& R. G. Cross, 'Artificial Intelligence Application in the Law: CCLIPS, a Computer Program That Processes Legal Information'

Goanta C, Van G. Dijck, \& Spanakis G, Back to the Future: Waves of Legal Scholarship on Artificial Intelligence, Forthcoming in Sofia Ranchordas and Yaniv Roznai, Time, Law and Change (Oxford Hart Publishing 2019)

Goltz N. \& Dondoli G, 'A note on science, legal research and artificial intelligence', (2019) 28 (3) Information \& Communications Technology Law

H. A. Yoon, 'Cognitive Computing and the Future of the Legal Profession', (2016) 66 University of Toronto Law Journal

Hellyer P, 'Assessing the Influence of Computer-Assisted Legal Research: A Study of California Supreme Court Opinions', (2005) 97 (2) Law Library Journal

Houlihan D, Ross Intelligence: Artificial Intelligence in Legal Research (Blue Hill Research 2017)

J. E. Schaal, 'Infringing a Fantasy: Future Obstacles Arise for the United States Patent Office and Software Manufacturers Utilizing Artificial Intelligence,' 11 (1) Villanova Sports \& Entertainment Law Journal

J. Manyika, M. Chui, M. Miremadi, J. Bughin, 'A future that works: automation, employment, and productivity', (2017) McKinsey Global Institute Technical Report.

Julius T. Buocz, 'Artificial Intelligence in Court Legitimacy Problems of AI Assistance in the Judiciary', (2018) 2 (1) Copenhagen Journal of Legal Studies

Krausova A, 'Intersections between Law and Artificial Intelligence', (2017) 27 (1)

International Journal of Computer

L. E. Rissland, 'Artificial Intelligence and Law: Stepping Stones to a Model of Legal Reasoning', (1990) 99 (8) Yale Law Journal

Legg M. \& Bell F, 'Artificial Intelligence and the Legal Profession A Primer', (2018) Law Society of New South Wales Flip Stream

Livingston S, and Risse M, 'the Future Impact of Artificial Intelligence on Humans and Human Rights, Ethics \& International Affairs', (2019) 33 (2) 
Martin D. Katz, 'Quantitative Legal Prediction-or-How I Learned to Stop Worrying and Start Preparing for the Data-Driven Future of the Legal Services Industry', (2013) 62 Emory Law Journal

McKamey M, 'Legal Technology: Artificial Intelligence and the Future of Law Practice', (2017) 22 Appeal Review of Current Law \& L.aw Reform

Medianik K, 'Artificially Intelligent Lawyers Updating the Model Rules of Professional Conduct in Accordance with the Technological era', (2018) 39 (4) Cardozo Law Review Melissa J. Perry, 'iDecide: Administrative Decision-Making in the Digital World' (2017) 91 Australian Law Journal

Mills M, 'Artificial Intelligence in Law: the State of Play' (2016)

Namisi N. Siboe, 'Herald! The Era of legal Artificial Intelligence in Legal Practice' (2019) The Law Society of Kenya Advocates Magazine, Annual Conference Edition,

Nikolas A, D. Tsarapatsanis, D. Preoţiuc-Pietro, V. Lampos, 'Predicting judicial decisions of the European Court of Human Rights: a Natural Language Processing perspective', (2016) 2 Peer Journal of Computer Science

N. S. Jain, 'Legal Research and Methodology', (1972) 14 (4) Journal of the Indian Law Institute

O. J. McGinnis \& G. R. Pearce, 'the Great Disruption: How Machine Intelligence Will Transform the Role of Lawyers in the Delivery of Legal Services', (2014) 82 (6) Fordham Law Review

Perel M. \& Elkin-Koren N, 'Black Box Tinkering: Beyond Disclosure in Algorithmic Enforcement' (2017) 69 (1) Florida Law Review

R. C. Sunstein, 'Of Artificial Intelligence and Legal Reasoning' (2001) University of Chicago Public Law \& Legal Theory Working Papers No. 18

R. J. Allison et al., 'Understanding the Realities of Modern Patent Litigation', (2014) 92 Texas Law Review 
R. M. Grossman \& V. G. Cormack, 'Technology-Assisted Review in E-Discovery Can Be More Effective and More Efficient Than Exhaustive Manual Review', (2011), 17 (3) Richmond Journal of Law \& Technology

Rodriguez T. De Las Heras Ballell, 'Legal Challenges of Artificial Intelligence: Modeling the Disruptive Features of Emerging Technologies and Assessing their Possible Legal Impact' (2019) 24 (2) Uniform Law Review

Samuel G, 'Chatbot lawyer overturns 160,000 parking tickets in London and new york', (2016) The Guardian

Scherer M, 'Artificial Intelligence and Legal Decision-Making: The Wide Open? Study on the Example of International Arbitration' (2019) Queen Mary University of London, School of Law Legal Studies Research Paper No. 318/2019

Semmler S, \& Zeeve Rose Z, 'Artificial Intelligence: Application Today and Implications Tomorrow' (2017) 16 Duke Law \& Technology Review

Simon M, Lindsay A, Sosa L \& Comparato P, 'Lola v. Skadden and the Automation of the Legal Profession', (2018) 20 Yale Journal of Law \& Technology

Sourdin T, 'Justice and Technological Innovation' (2015) 25 Journal of Judicial Administration

Stankovic M, Gupta R, Andre B. 'Exploring Legal, Ethical and Policy Implications of Artificial Intelligence', (2017) Law, Justice, and Development White Paper

T. Hutchinson and N. Duncan, 'Defining and Describing What We Do: Doctrinal Legal Research', (2012) 17 (1) Deakin Law Review

Tsang L, A. Daniel K., Mulryne J, \& et al, 'The Impact of Artificial Intelligence on Medical Innovation in the European Union and the United States', (2017) 29 (8) Intellectual Property \& Technology Law Journal

W. D. Vick, 'Interdisciplinary and the Discipline of Law', (2004) 31 (2) Journal of Law and Society

W. J. Creswell, Educational Research: Planning, Conducting and Evaluating Quantitative and Qualitative Research (3rd edn., Pearson 2008) 


\section{Reports}

'Guidelines for Collecting and Reporting Data on Research and Experimental Development, The Measurement of Scientific, Technological and Innovation Activities', (OECD Publishing 2015)

'Digital Economy Outlook' (OECD Publishing 2017)

‘Artificial Intelligence and the Legal Profession', (2018) the Law Society of England and Wales Report

‘Artificial Intelligence in Society’, (OECD Publishing 2019)

‘Artificial Intelligence', (2019) WIPO Technology Trends Executive Summary

'The EU Declaration on Cooperation on Artificial Intelligence', (2018); 'The European

Parliament resolution on Civil Law Rules on Robotics' (2015/2103(INL)) (2018/C 252/25)

\section{Case Laws}

Moore vs Publicis Groupe 287 FRD 182 (SDNY 2012

Irish Bank Resolution Corporation Limited v Quinn [2015] IEHC 175

Pyrrho Investments Ltd v MWB Property Ltd [2016] EWHC 256 (Ch)

McConnell Dowell Constructors (Aust) Pty Ltd v Santam Ltd and Others (No 1) [2016] VSC 734 (Vickery J) (“McConnell Dowell”)

Brown v BCA

Triumph v Primus 